\title{
River and labour in Samuel Scott's Thames views in the mid-eighteenth century
}

\author{
Markman Ellis, QMUL, April 2012, v4 \\ [post-print (ie final draft post-refereeing)] \\ as published in The London Fournal, Vol. 37 No. 3, November 2012, 152-73
}

This paper focuses on literary and visual tropes associated with the social and commercial life of the Thames in London in the mid-eighteenth century. These tropes are elaborated and sustained in visual culture, both topographical painting and satires and in poetry, both descriptive verse such as the georgic and the ode. Analysis of these riverine poetic tropes will afford some insight into the Thames paintings of Samuel Scott (1710-1772), not in order to demonstrate a relation of influence, nor to illustrate the discourse of the sister arts, but rather, to provide some contemporary language in which Scott's curiosity about the painterly potential of the river, its shipping, and the labour of its workers, might be understood. The georgic in particular offered poets a mode that seemed to reconcile the commercial prosperity of the City with the aristocratic and royal power associated with Westminster. In the georgic verse of Pope and Dyer, these rival cultural formations could be shown to be coterminous and mutually dependent, especially in praise of the virtues of labour and consumption, and the prosperity engendered by domestic and international trade. However, as the critics surveyed below have argued, in achieving this reconciliation between the commercial and aristocratic interest, the georgic suppressed recalcitrant and unlovely aspects of the modern economy, such as the physical strenuousness of labour, the exploitation of the poor, and forms of coerced labour such as indenture and slavery. Scott's paintings give further evidence of the tensions, both creative and contradictory, implicit in representations of commercial prowess and the labouring poor in this period.

In the eighteenth century, the Thames was the subject of panegyric and praise by poets: Pope referred to it as the 'great Father of the British Floods' in Windsor Forest (1713), ${ }^{1}$ a conceit echoed in George Jeffrey's News Year's ode in 1720, when he referred to the river as 'King of the Floods! Britannia's Darling'.2 Such descriptions point to the geographical significance of the river: it is a substantial watercourse, over

1 Alexander Pope, 'Windsor Forest' (1713), in Pastoral Poetry and An Essay on Criticism, ed. by E. Audra and Aubrey Williams, The Twickenham Edition of the Poems of Alexander Pope, ed. John Butt, 10 vols (London: Methuen, 1939-67), I, (1961), p. 169, 1. 219.

2 George Jeffreys, 'Ode for New-Year's-Day, 1720. To the Thames. Written at the Request of Mr. Rowe, Poet-Laureat', in Miscellanies, in verse and prose (London: printed for the author, 1754), p. 57-58. 
215 miles long, flowing from the hills of Gloucestershire to its estuary between Kent and Essex. But this language also points to the human - cultural, economic, and social - significance of the Thames both to London and the nation. The Port of London was the largest in Britain in the eighteenth century, whether measured by the values of imports and exports, or the number and tonnage of ships using the port. Before the dock boom of the 1790s, which saw the construction of the West India Quays on the Isle of Dogs, almost all shipping was handled within the Pool of London, an area just below London Bridge. ${ }^{3}$ Above London bridge, where the seagoing vessels could not pass, the river was still an important waterway, busy with city river traffic. A French visitor, Charles Moritz, observed in 1782:

On the Thames itself are countless swarms of little boats passing and repassing, many with one mast and one sail, and many with none, in which persons of all ranks are carried over. Thus, there is hardly less stir and bustle on this river, than there is in some of its own London's crowded streets. ${ }^{4}$

The river served as an important medium of transport for people and for commodities, and supported a distinctive riverine labour culture. ${ }^{5}$ Watermen, much like hackney coaches or modern taxis, picked up passengers and transported them to and from designated destinations, at stairs and wharves. Lightermen used large flatbottomed sailing barges to transport goods and commodities of the inland trade. ${ }^{6}$ The river was, furthermore, the location for an important fishery (herring, flounder, salmon, even sturgeon were all caught in the river), and as such an important food resource for the city. ${ }^{7}$ In their mutual encouragement of prosperity and civic grandeur, London and the Thames shared a coextensive fate, as Dryden observed in 'Annus Mirabilis: The Year of Wonders, 1666'. Having described the battles of the Anglo-Dutch war and the fire of London, at the end of the poem, Dryden looks forward to the reconstruction of London's prosperity.

Now, like a maiden queen, she [London] will behold,

From her high turrets, hourly suitors come:

The east with incense, and the west with gold,

\footnotetext{
3 Walter Stern, 'The First London Dock Boom and the Growth of the West India Docks', Economica, New Series, 19: 73 (February 1952), pp. 59-77.

4 Charles Moritz, Travels, Chiefly on Foot, Through Several Parts of England in 1782 Described in a Letter to a Friend, trans. by 'A Lady' (London: G. G. and J. Robinson, 1795), p. 11.

5 Marcus Rediker, Between the Devil and the Deep Blue Sea: Merchant Seamen, Pirates, and the Anglo-American Maritime World, 1700-1750 (Cambridge: Cambridge University Press, 1989), pp. 24-34.

6 David Wood, The last berth of the Sailorman: research report [for] The Society for Sailing Barge Research (Twickenham: The Society, 1996); Derek Coombe, The London river E Kentish shore, 2nd edn (Bosham: Pennant Books, 2008).

7 Roger Griffiths, A description of the River Thames, Ec. with the City of London's jurisdiction and conservacy thereof proved, Both in Point of Right and Usage (London: printed for T. Longman in Pater-Noster-Row, 1758)
} 
Will stand, like suppliants, to receive her doom.

The silver Thames, her own domestic flood, Shall bear her vessels like a sweeping train;

And often wind, as of his mistress proud,

With longing eyes to meet her face again. ${ }^{8}$

By imagining ships and exotic goods flooding up the Thames to the city, Dryden reverses the cornucopia trope, distinctively feminizing his depiction of the city and the river to make legible the consumer desire (demand) that drives this prosperity.

\section{Samuel Scott}

Contemporaries understood Scott as a sea-painter, for it was as a marine artist that he first came to notice, with a series of seascapes depicting naval engagements. Horace Walpole said of him that he was 'a painter of sea-pieces [...] born for an age of naval glory'. Scott is known to have studied the marine paintings and drawing of Van de Velde, and was an expert in the technical accuracy of his shipping, and their mis en scene in aquatic environments. Between 1745 and his death in 1772, Scott completed a series of paintings in oil (at least 62) that depict Thames-side scenes. Many of these views depicted the same scene from the same point of view: Richard Kingzett's 'Catalogue' of the works of Samuel Scott for the Walpole Society (1982) establishes that Scott's river paintings are restricted to only 20 distinct views. ${ }^{9}$ In painting the same scene again and again, Scott was responding to the economic realities of the market, as popular views were re-commissioned by numerous patrons.

All but one of Scott's London paintings use the Thames as a watery element in the foreground, populated by river craft, together with riverside buildings forming a topographical townscape. The paintings are thus a sort of maritime landscape, a hybrid between the marine and the topographical, although unlike a topographical artist, Scott departed from strict topographical accuracy on occasion, adjusting buildings, adding or deleting spires, and omitting material from the background. The foreground of his paintings, however, continued his marine interest in shipping and boats, offered in meticulous detail, and manned by numerous figures. In the most sustained and rewarding recent work on Scott, Sarah Monks entwines her reading of the ideology of Scott's depiction of downstream river traffic, with the location of the paintings within their own commercial system, that of elite patronage, by wealthy citizens and aristocracy. Scott's repetitive depiction of the same restricted set of scenes,

\footnotetext{
8 The Works of John Dryden: Volume I Poems 1649-1680, ed. by Edward N Hooker and H. T. Swedenberg, Jr. (Berkeley and Los Angeles: University of California Press, 1961), 47-105, 1l. 1186-93.

${ }^{9}$ Richard Kingzett, 'A Catalogue of the Works of Samuel Scott', Walpole Society 1980-1982, 48, (1982), pp.1-134. In using Kingzett's topographically organized catalogue, this article includes views located in Wapping, Rotherhithe and Chelsea within the remit of the Thames in London.
} 
Monks shows, is explained by the economic realities of the studio system, as versions of the same scene were painted on commission. It is notable that while the viewpoint stays the same in each iteration (being based on the same preliminary drawings), Scott varies the figures and shipping in almost every case. Kingzett notes that it seems to have been a point of honour for him to vary the figures and the shipping in each case. No two are identical in their staffage'. ${ }^{10}$ The patronage system, as Monks explains, also required that while a view might be repeated in a new commission, the work should be a version and not a copy of its predecessor. The variety nonetheless heightens curiosity about the role of shipping and staffage (accessory figures in landscape painting) in the works. While these are not paintings of river people in any orthodox sense (portraits or genre painting), the place of the figures, and their engagement in forms of labour and leisure, repay some attention. ${ }^{11}$ This essay considers Scott's Thames views through their different scenes of labour, at the pool, quay, and bridge. It explores the representation of topography and labour in these river-side paintings through the discourse of georgic, thinking about diverse ways of organizing the relationship between water and land, and the different scenes of labour and leisure they support.

\section{Pool}

The 'Pool of London' refers to the part of the Thames between London Bridge and Cuckold's Point, the busiest part of the river, congested with shipping and small boats. The focus for this commercial activity was a set of quays, known as the 'Legal Quays', between London Bridge and the Tower, where all cargoes imported from outside the kingdom had to be delivered for inspection and assessment by Customs Officers at a series of quays. The congested throng of shipping in the pool was a notorious spectacle in the period: as one French visitor, Jacques Henri Meister suggested in 1791, 'to take a view of the extent and grandeur of the commerce of this first trading nation in the world, you must [...] take boat to go down the Thames, and see the bosom of that noble river bearing thousands and thousands of vessels, some sailing up or down, going or coming from every part of the world, and others moored in five or six tiers as closely to each other as it is possible for them to be'. ${ }^{12}$ Daniel Defoe, in his Tour thro' the whole island of Great Britain in 1727, thought the spectacle sublime, beyond the ability of any writer 'to bring it into any reasonable Compass'. In his estimation, there were

10 Kingzett, p. 4.

11 Richard Quaintance, 'Who's making the scene? Real people in eighteenth-century topographical prints', in The country and the city revisited: England and the politics of culture, 1550-1850, edited by Gerald MacLean, Donna Landry, and Joseph P. Ward (Cambridge: Cambridge University Press, 1999), pp. 134-59

12 Jacques Henri Meister, Letters written during a residence in England (London: T. N. Longman, 1799), p. 17-18. 
in the Pool 'above Two thousand Sail of all Sorts, not reckoning Barges, Lighters or Pleasure-Boats, and Yachts; but of Vessels that really go to Sea'. ${ }^{13}$

The view of shipping at anchor in the Pool is depicted in Scott's The Thames and the Tower of London Supposedly on the King's Birthday (1771, Yale Centre for British Art) [Figure 1], exhibited at the Royal Academy in 1771, and raffled in Bath at Mr Gydes Great Room in April 1772 to fifty subscribers at 2 guineas each. The prospect, taken from the South Bank at Bermondsey, is dominated by the bulk of the Tower, with its massive royal standard reiterating its role as an emblem of royal and state power, and to the left, the topographical interest of numerous church spires, the Monument, and St Paul's. The main foreground focus is the shipping in the river, dominating the scene in the manner of Scott's earlier maritime paintings in the Van de Velde tradition. ${ }^{14}$ In the foreground is a two-masted ketch-rigged sailing barge flying a Dutch flag, about to take on a miscellaneous cargo of barrels, bales and crates from a group of three watermen in diverse lighters. A somewhat laconic sailor peers over the broad gunwhale of the barge, observing the waiting lightermen pulled up below him. Beyond the labour-drama of the barge, there is the crowded activity of the quay below the Tower, and the miscellaneous shipping and warehouses there. In the centre, screened by bustle around the ketch, a frigate fires a salute with a canon-shot, perhaps in recognition of the King's Birthday, as noticed in the title. And to the far right, balancing the view, is the crowded shipping at anchor in the pool, so thickly moored together that their masts appear like a forest. Scott's Thames is a scene both of royal or national power, and commercial activity. In another view near to this scene, The Pool of London (Guildhall Art Gallery, 1769), taken from further downstream in Rotherhithe, Scott narrows the view so as to omit the Tower and open up the vista to St Paul's in the distance, while a hoy works in close to decayed river buildings on the shore. In the mid-stream of the river, to the far right, the larger ocean-going East India Company vessels and other ships lie in their deep anchorage, their numerous masts affording a side-screen to the view. Scott's depictions of the Pool, as the travel writing of Meister and Defoe testify, see the spectacle of assembled shipping as a view of some tropological suggestiveness, reiterating the role of commerce in ideas of nation.

\section{The Forest of Masts Trope}

By way of exploration of the commercial argument of these painting of the Thames, I want to turn to the treatment of trade in descriptive poetry about London and the Thames in the eighteenth century, beginning with Pope's poem Windsor Forest,

\footnotetext{
13 Daniel Defoe, A Tour thro' the whole island of Great Britain, Divided into Circuits or Fournies, 2 vols (London: Frank Cass \& Co., 1968), I, Letter 5, pp 349-50.

14 Michael S. Robinson, A catalogue of the drawings in the National Maritime Museum made by the Elder and the Younger William van de Velde, 2 vols (Cambridge: University Press, 1974).
} 
published in 1713. A river generates a lot of metaphors: a common reader might think of the stream of consciousness, the river as a symbol of eternity, as a metaphor for the course of human life, as a mirror of the nation. ${ }^{15}$ Early modern English river poetry by Spenser, Camden and Drayton found much potential in the trope of the marriage of rivers. ${ }^{16}$ For example, in The Faerie Queene (1590), Spenser devotes forty-six stanzas to a description of the meeting of the Thames and the Medway, imagining their confluence as a marriage enacted between the personified rivers in a ceremony attended by diverse sea gods. ${ }^{17}$ In addressing the Thames in Windsor Forest, Pope borrows important themes and language from the marriage of rivers trope, especially the conceit of personifying of the river in terms of a mythological figure. But, like other poets in the eighteenth century, he also experimented with these inherited poetic commonplaces, innovating new ways of representing the river and its world. One such example is what will here be called the 'forest of masts' trope, developed from the description of the crowd of ships assembled at the docks in the London pool, so thickly grouped that their masts seems like a forest. By way of introduction to this image, here is a fictional prose account by Lydia Melford in Tobias Smollett's comic novel, The Expedition of Humphry Clinker (1771). Melford is a credulous excited reader, who is having her first view of 'The cities of London and Westminster', which she says 'are spread out into an incredible extent'. The crowds of people, and their splendid equipages, make her quite giddy. The Thames too astonishes her:

Nor is the prospect by water less grand and astonishing than that by land: you see three stupendous bridges, joining the opposite banks of a broad, deep, and rapid river; so vast, so stately, so elegant, that they seem to be the work of giants: betwixt them, the whole surface of the Thames is covered with small vessels, barges, boats, and wherries, pasting to and fro; and below the three bridges, such a prodigious forest of masts, for miles together, that you would think all the ships in the universe were here assembled. ${ }^{18}$

\footnotetext{
15 A list developed from Peter Ackroyd, 'The River as Metaphor', in Thames: Sacred River (London: Chatto and Windus, 2007), pp. 7-10. See also Jonathan Schneer, The Thames: England's river (London: Little, Brown, 2005), and Anna Adams (ed.), Thames: an anthology of river poems (London: Enitharmon, 1999).

16 Pat Rogers, 'Windsor-Forest, Britannia and River Poetry', Studies in Philology, 77: 3 (Summer, 1980), pp. 283-299 (283-84).

17 Edmund Spenser, The Faerie Qveene, ed. by A. C. Hamilton, $2^{\text {nd }}$ edn (London: Pearson Harlow, 2007), IV, xi, 8-53 (pp. 492-501). Camden's De Connubio Tamae et Isis was translated as 'The marriage of the Thames and Isis' by Kennet, in William Camden, Camden's Britannia, newly translated into English: with large additions and improvements Publish'd by Edmund Gibson, of Queens-College in Oxford (London: printed by F. Collins, for A. Swalle, at the Unicorn at the west-end of St. Paul's Church-yard; and A. \& J. Churchil, at the Black Swan in Pater-noster-Row, 1695).

18 Lydia Melford to Lætitia Willis at Gloucester, London, May 31, The Expedition of Humphry Clinker, ed. by Lewis M. Knapp and Paul-Gabriel Boucé (Oxford: Oxford University Press, 1984), pp. 90-91.
} 
The spectacle of the forest of masts appealed to painters after Scott too: Thomas Luny, in his The Port of London (1798, Yale Centre for British Art), [Figure 2] made the prodigious assembly of ships in the pool a foil for his fanciful view of the projected new London Bridge (depicted as imagined, not as subsequently built in 1825).

In Pope's Windsor Forest the treatment of the commercial spectacle of the port of London is less excited, but clearly on the same tropological spectrum as Smollett's forest of masts. Pope's poem has already examined and celebrated the royal forests at Windsor, exploring the ancient oaks as a metaphor for royal power, first under the Normans (1l. 43-92), and later, through the Tudors and Stuarts. In the final section, the spatial focus of the poem migrates downriver, from Windsor to Cooper's Hill, and thence to the cities of London and Westminster, and by this spatial transition, brings itself up to the present, the reign of Anne. The river god, Father Thames, proclaims:

Behold! Augusta's glitt'ring spires increase,

And temples rise, the beauteous works of Peace.

I see, I see where two fair cities bend

Their ample bow, a new White-hall ascend! (377-380)

London is the emblem of prosperity and piety, two cities at the bend of a river, one a seat of royal power, the other of commerce and finance. In Pope's view Augusta or London is a place of building and rebuilding: new churches with glittering spires being erected by under Queen Anne's Fifty New Churches initiative, and renewal, in the form of the rebuilding of Whitehall after the destructive fire of 1698. In bringing the poem into the present, Pope reinforces the mercantile Whig argument of the virtue of international commerce. ${ }^{19}$

The poet links the prospect of the city, and its prosperity, to the forest through a concealed or embedded metaphor of the masts:

Thy trees, fair Windsor! now shall leave their woods,

And half thy forests rush into my floods,

Bear Britain's thunder, and her Cross display,

To the bright regions of the rising day;

Tempt icy seas, where scarce the waters roll,

Where clearer flames glow round the frozen Pole;

Or under southern skies exalt their sails,

Led by new stars, and borne by spicy gales! (1l. 385-92)

The forests of oak transform themselves, seemingly through their own volition, into the ships - planking, decking, masts - upon which commercial prosperity and naval power are based. These ships are armed (the 'thunder' of the guns) and bear the English flag, with its 'Cross' of St George. Pope constructs a new trope here,

19 Earl Reeves Wasserman, The Subtler Language. Critical readings of neoclassic and romantic poems (Baltimore: Johns Hopkins Press, 1959) 
envisaging the river as the focus of a trading empire. As the lines proceed, this becomes a prophecy about Britain's providential future in global empire:

The time shall come, when free as seas or wind

Unbounded Thames shall flow for all mankind,

Whole nations enter with each swelling tyde,

And seas but join the regions they divide;

Earth's distant ends our glory shall behold,

And the new world launch forth to seek the old. (11. 397-402)

The static and pictorial concentration of shipping in the Thames can now be read as evidence of the active and growing power of the British commercial empire, won for trade and not dominion, as Pat Rogers has argued. ${ }^{20}$ In the final section here, Pope repurposes Dryden's trope of the cornucopia reversed, by imagining the prophetic, yet seemingly risible, notion of ships from the imperium coming to trade with Britain, with their 'feather'd people [...], And naked youths and painted chiefs' (1l. 404-5). This new prosperous and commercial empire, an maritime empire of islands and colonies abroad, will bring wealth and peace, unlike the violence and cruelty of the discord of the previous century, or the absolutist tyranny of continental empire building.

As a commercially oriented painter, Scott was aware of the strong market for topographical views of London, especially amongst aristocratic and elite circles. The arrival in London of Canaletto (Giovanni Antonio Canal, 1697-1768) in May 1746, where he stayed until 1755, may have been an impetus for his turn to town-scape painting, although Scott was already pursuing his interest in these topographical urban views before he arrived. Canaletto's arrival, and celebrated success at these views, raised the profile of vedute painting by stimulating the market for them, and renovating their composition and style. ${ }^{21}$ Amongst the most celebrated of Canaletto's paintings were his Thames views, such as The Thames and the City of London from Richmond House (1747, Trustees of Goodwood House), which depicts a view taken from an upper window of Richmond House, home of Charles Lennox, Duke of Richmond (1701-1750), looking around the curve of the river, towards the great dome of St Paul's, the numerous church spires, and the river 'festively alive' (as Liversidge says) with 'livery company barges and a profusion of smaller boats'. ${ }^{22}$ Mark Hallett has argued that this high and privileged viewpoint offers 'a new pictorial definition of

\footnotetext{
20 Pat Rogers, 'Trade and Empire: Annus Mirabilis and Windsor-Forest', Durham University fournal, LXIX (1976), 14-20 (p. 19).

21 Kingzett, p. 2; Michael Liversidge, 'Canaletto and English Painters', in Canaletto E England: the Catalogue Accompanies the Exhibition Held at Birmingham Gas Hall Exhibition Gallery, 14 October 1993-9 January 1994 (London: Merrel Holberton, 1993), pp. 104-117 (p. 111).

22 Liversidge, Canaletto \& England, p. 21. See also John Eglin, 'Venice on the Thames: Venetian Vedutisti and the London View in the Eighteenth Century', in Italian culture in northern Europe in the eighteenth century, edited by Shearer West (Cambridge: Cambridge University Press, 1998), pp. 101-115.
} 
aristocratic authority in the metropolitan environment, one that sought to reconcile the signs of elite status with the spaces of popular and bourgeois culture'.23 Taken from this high viewpoint at the court end of town, towards the commercial splendours of the city, looking out over the noble terrace, towards the profusion of boats on the river, with their mixture of the everyday and the ceremonial. In the service of this polite refinement, Canaletto seems to have edited the river traffic, depicting the river populated only by personal and civic craft, comprising watermen in their wherries, and civic barges of the livery companies and other official boats. By comparison with Scott's views, Canaletto's river has been emptied of commercial barges carrying cargo. ${ }^{24}$ In addition, some have found that Canaletto's London views have a falsely Italian brightness to them (what Ellis Waterhouse called this 'almost factitious sparkle'), ${ }^{25}$ where by contrast, Scott is more curious about depicting London's smoky and overcast skies, and the gloomy effects it has on the river's water. ${ }^{26}$ In these diverse ways, it has been argued that Canaletto's Thames-side views offer a polite and sanitized view suitable for a noble household.

The influence of Canaletto on English townscape painting can be seen in The Entrance to the River Fleet (undated, Guildhall Art Gallery) [Figure 3], no longer attributed to Scott. The anonymous painter reorganises the quay into a more polite image in imitation of Canaletto's images of Venetian canals. It depicts the Thames quays at the entrance to the Fleet as a scene of industry and leisure, including within the view three West Country barges, a sprit-rigged sailing barge, wherries carrying passengers and cargoes, and a party of pleasure in a double-oared waterman's boat. ${ }^{27}$ The view seems to overlook the tidal range of the Thames: the scene is painted on a calm day at high tide, when the entrance to the Fleet Ditch is depicted in Venetianised splendour. The canal of Fleet Ditch was notoriously unpleasant: smelly, polluted and muddy, lined with decaying houses, butcher's yards and tanners, the 'Cloaca Maxima' of the city yet in this polite view, it is lined with elegant houses, and crossed by a fanciful Venetian bridge, standing for the low twin arched stone structure of the real Bridewell bridge. Fleet Ditch itself was turned into a culvert in 1765 during the building of Blackfriars Bridge. The painter's factitious Venetianising may have served to draw

\footnotetext{
23 Mark Hallett, 'Framing the Modern City: Canaletto's Images of London', in Liversidge, Canaletto $\mathcal{E}^{\circ}$ England, $46-54$ (p. 46).

24 The preparatory drawing (The Thames and the City from Richmond House, 1746, pen and brown ink with grey wash, 33.7x54cm, Birmingham Museums and Art Gallery) has noticeably more craft on the river, including a series of sailing barges. See Charles Beddington, Canaletto in England: A Venetian Artist Abroad, 1746-1755, (New Haven, GT: Yale University Press, 2006), cat. no. 21, p. 96.

25 Ellis Kirkham Waterhouse, Painting in Britain, 1530 to 1790, Pelican history of art (London: Penguin Books, 1953), p. 116.

26 Kingzett, p. 2, Liversidge, Canaletto \& England, p. 112.

27 As detailed on Roque's map, the quays in question are: on the left of the canal, the Timber Yard at Dorset Stairs, and on the right, Blackfryars Stairs, with waterman's boats pulled up like gondolas.
} 
comparisons between Venice and London, although the notoriety of the Fleet may equally have served to undermine any close comparisons.

\section{Quay}

Scott evidently saw creative potential in the quay, as a site that combined his interest in the scene of labour with a broader and more politically focused notion of commerce. This is seen in his views of Custom House quay, extant in two upright canvasses, an unusual format for Scott. The first and smaller view is titled as Custom House and Wool Quay in the year 1757 (1757) [Figure 4], in the Fishmongers' Company, and the second now known as A Thames Wharf (1757), in the Victoria and Albert Museum, but was acquired by the museum under the title of The Old East India Wharf at London Bridge, with an older label on the stretcher inscribed The Old Custom House. ${ }^{2}$ Although the two versions are broadly similar, they do have slight differences: the later painting in the V\&A has a man lowering a barrel from a high-level warehouse using a gantry crane attached to the wall of the building, and a dog in centre foreground. ${ }^{29} \mathrm{In}$ the absence of definitive evidence, and in light of the activities it depicts, this article describes the view as a somewhat fictitious account of the quay known as Custom House and Wool Quay in the year 1757, following the label on The Fishmongers' Company version. The painting depicts a quay on the north bank of the river, with warehouse buildings on the right, of modern brick construction, but with weatherboard crane housings in some disrepair, one with a spiral staircase and the other with a large circular treadmill for a massive cantilevered wooden crane. In the river are two large vessels, one on the left a port bow view of a ship flying a commodore's pennant, on the right a port stern view of another: the deck of both ships crowded with people unloading into a tender. On the quay on the left there is a boy fishing (he has caught a skate), and two men loading goods onto a cart, an uncoupled team of dray horses to the right. Diverse goods (barrels, jars, bales, cases) are piled on the wharf at left and right. In the background more men unload goods. In the right foreground, there are further diverse goods in barrels, bales, crates and jars,

\footnotetext{
28 Kingzett G1 and G2 (pp. 41-42). Kingzett argues that the buildings depicted are not congruent with the stated location, and renames both as The So Called Custom House Quay. The Fishmongers' Company painting was acquired in 1858, with the title named here, from the sale of Sir Edward Walpole's collection, who may have acquired it from the painter, with whom he was acquainted since the 1730s. Although this provenance may give some authority to the Fishmongers' label, no definitive title given by Scott can be ascribed to G1. G2 was exhibited at the Society of Artists by Scott in 1764 as $A$ view of Bear Quay, and was described in Lot 83 in Scott's Studio Sale of 4 April 1765 as 'An upright view of Bear Key, with figures and merchandise' (Kingzett, p. 41). Monks argues (in 'The Downriver Thames', pp. 18-19) that G2 depicts Bear Key, supported by internal evidence and the 1764 exhibition title. Bear Quay was adjacent to Custom House quay.

29 Kingzett argues the dog is based on a drawing by Scott's apprentice Sawrey Gilpin, p. 42. See Sawrey Gilpin, A spaniel guarding its master's stick (1758), British Museum Department of Prints and Drawings, No. AN314114001, Location: British Roy PIIIb.
} 
some marked with numbers and merchants' marks, including one jar with a luscious striped cloth spilling out.

The arrangement of goods on the quay suggests the visual trope of the cornucopia. One bale is noticeably marked with the merchants' mark of the United East India Company: the 'Sign of Four' made up of a cross and the figure of the Arabic numeral '4', with a heart shaped lozenge below, divided by a saltire, with the initials of the company (VEIG) in each quarter. This mark served as a trademark for the company, used on its bale marks, trade tokens, and coinage, and was very widely recognized in the period. ${ }^{30}$ The narrative focus of the painting is located in the three men in the foreground centre-right, meeting around an up-turned crate. A well-dressed officer of the Customs (properly, a 'Land-waiter'), wearing a blue coat, tri-corn hat and white stockings, enters figures in a ledger with a quill pen, while before him two men, wearing the typical costume of seamen, in caps, jackets and canvas trousers, look on. ${ }^{31}$ These men, one with his hands in his pockets, the other smoking, are clearly at leisure. On the far right, three workmen, dressed in aprons, work at the barrels (coopers or porters closing them up after inspection). This encounter has been understood, by Kingzett and Monks, to represent a seaman or sea captain undergoing a customs inspection on their cargo, deposited on the quay around them. ${ }^{32}$ The bale marked with the East India Company mark makes sense of the scene and the location: these are goods imported as part of the seamen's private trade, items brought back under allowance for their own profit. The East India Company ships were closely controlled by the Customs after their arrival in the Thames, escorted by Customs cutters. While the Company's goods and those of the 'private trade' - those on freight for other merchants - were taken direct to the East India warehouses near Crutched Friars, 'The goods belonging to the master, officers and crew were placed in the King's Warehouse at the Custom House'. The crew and officers were permitted to trade privately on their own behalf on each voyage: many made large sums on each voyage. 'At all stages of these operations full accounts of all the goods landed were taken by the Customs officers." 33 The customs encounter in the foreground identifies the location as the Custom House quay, and makes sense of both of the titles given to the painting by Scott.

\footnotetext{
30 William Boyne, Tokens Issued in the Seventeenth Century in England, Wales, and Ireland, By Corporations, Merchants, Tradesmen, Etc. (London: J.R. Smith, 1858), p. xvii.

31 Landwaiter: 'a customs officer whose duty is to superintend the landing of goods and to examine them' OED. See 'Directions for Mercantile Business' in The universal library of trade and commerce (London: printed for J. Robinson, 1747), p. 28

32 Kingzett, p. 42; Monks pp. 5-6.

33 Graham Smith, Something to Declare: 1000 Tears of Customs and Excise (London: Harrap, 1980), p. 64.
} 
Scott's painting, it can be argued, is in dialogue with a satire from earlier the same year by the French engraver Louis Philippe Boitard, entitled The Imports of Great Britain from France, published by John Bowles in March 1757 [Figure 5]. ${ }^{34}$ Boitard's print depicts a topographically recognizable Custom House quay, with the Tower in the distance, and to the right, the crowd of vessels in the pool, with their forest of masts. The quay-side is dominated by four large crane housings, the treadmill visible through the door. To the right a French packet lands passengers wearing outlandish French fashions. In the foreground are a large pile of imported French luxuries, including (as the caption makes clear) barrels of claret, burgundy and champagne, together with an open barrel of stinking Normandy cheeses, a packing case containing bottles of French perfume, destined for 'Monsieur Pomade', and further crates containing millinery, ruffs and ribands. Four tackle porters carry off a huge case of the latest French fashions to an English nobleman in St James. Boitard's satire comments on the excessive desire amongst the English for French luxuries, especially incongruous in this year of 1757, the second year of the Seven Year's War between Britain and France. A more specific subject of the satire is the Anti-Gallican Society, formed around 1745 to campaign against the pervasive and corrupting French influence on English culture and commerce. Verse satirists and polemicists in the mid 1750s found ample scope in the hypocrisy of this English desire for French fashions in a period of international hostility and rivalry. ${ }^{35}$ Boitard's satire, with its foreground cornucopia of imported luxuries, sees foreign trade and commerce as a corrosive force in British society. Scott's painting, completed later in the same year (more precise dating is not possible), is a visual and ideological riposte to Boitard's satire. Scott's quay is an orderly scene of administrative action, as the customs officer processes the imports in proper form, under the regulations of a legitimate form of trade. Moreover, although the goods are imported, they are readable as British in origin, being sourced by the East India Company from their factories in the orient. ${ }^{36}$ In Scott's mercantilist view, transoceanic international trade within the empire - that which will come to be known as the British Empire within the next decade - reinforces the strength and

34 Louis Philippe Boitard, The Imports of Great Britain from France. Humbly addressed to the Laudable Associations of Anti-Gallicans, and the generous promoters of the British Arts \& Manufactories (London: Invented \& Engrav'd by L.P. Boitard. Publish'd according to the Act of Parliament, March 7th 1757 by John Bowles and Son at the Black Horse in Cornhill, 1757), in Catalogue of political and personal satires preserved in the Department of Prints and Drawings in the British Museum (London: the British Museum, 1952), No. 3653. Boitard's preliminary study for the satire in pen and brown ink is in the British Museum Department of Prints and Drawings (AN161252001, location: British Roy PIIIb).

35 Britain, strike home. A poem. Humbly Inscribed to every Briton. By a true Antigallican (London: printed for T. Legg, 1756). See also D.G.C. Allan, 'The Laudable Association of Anti-Gallicans', fournal of the Royal Society Arts, 137 (1989), pp. 623-628.

36 Monks comments on this encounter as possessing a 'sense of easy purposefulness' by which 'signs of labour are softened' (p. 6), but draws a different conclusion. 
prosperity of the nation. ${ }^{37}$ Scott's painting finds its location within the period's characteristic notion of maritime empire, one motivated by commerce, bringing peace and civilisation to islands and plantations widely separated by seas and oceans, that which James Thomson calls the 'well earned Empire of the Deep'. ${ }^{38}$

\section{Georgic and commerce}

In exploring Scott's curiosity about the presence of the labour and leisure on the river, poetry again establishes a context, especially that of the georgic. As critics have argued recently, in the eighteenth century the georgic form offered a felicitous mode for the description of the virtues of labour and commerce. English georgics were modeled on Virgil's Georgics, a long poem in four books, written between 37-30 BC, on the subject of agriculture and husbandry. ${ }^{39}$ Eighteenth-century poets found in the classical genre of the georgic a creative mode of experiment and imitation. In John Dyer's The Fleece (1757), a formal four-book georgic on the wool trade, the reader is taken from rural world of pasture, sheep and shepherd, through to the manufacture of woolen textiles and their export to grateful nations around the world. The georgic, in short, offered a mode in which the minutiae of British rural life - activities such as tupping and shearing - could be expansively linked with the great national themes of trade and empire. As critics have argued, the georgic form celebrates the virtue of labour, albeit without much sympathy for the burden of work, or much practical knowledge of its mysteries. ${ }^{40}$ Nonetheless, by championing the work of the labouring poor, insisting on its virtue and pleasures, reiterating its higher purpose in the national destiny, linking it explicitly to the grander themes of commerce and to public prosperity, the georgic mode celebrates both labour and trade. In this way, the georgic reimagined the country and the city, revising the negative pastoral depiction of the city in a more

37 Although the term 'British Empire' was not commonly used to refer to territories under British or EIC control in South Asia until the 1760s, poets and historians used the notion of empire to refer to overseas British plantations and colonies in the Caribbean, North America, and elsewhere from the early decades of the eighteenth century. See for example John Oldmixon, The British Empire in America, containing the history of the discovery, settlement, progress and present state of all the British colonies, on the continent and islands of America, 2 vols (London: printed for John Nicholson, Benjamin Tooke, and Richard Parker and Ralph Smith, 1708). See David Armitage The Ideological Origins of the British Empire (Cambridge: Cambridge University Press, 2000) and Markman Ellis, 'Islands of empire: the West Indies in eighteenth-century georgic and pastoral poetry', in Islands in History and Representation, ed. Rod Edmond and Vanessa Smith (London: Routledge, 2003), pp. 120-42.

38 James Thomson, Britannia, A Poem (1729), in Liberty, The Castle of Indolence and Other Poems, ed. by James Sambrook (Oxford: Clarendon Press, 1986), p. 26, 1. 167.

39 Publius Vergilius Maro (Virgil), Eclogues, Georgics, Aeneid I-IV, trans. by H. Rushton Fairclough, rev. G.P. Goold, Loeb Classical Library, No. 63 (London and Cambridge, Mass.: Harvard University Press, 1999).

40 See for example John Barrell, The Idea of Landscape and the Sense of Place 1730-1840 (Cambridge: Cambridge University Press, 1980), pp. 37-38; John Goodridge, Rural Life in Eighteenth-Century English Poetry (Cambridge: Cambridge University Press, 2005). 
positive mode as the location of the market, as a place of consumption, and, in the vision of the port, as a place of exportation, thus forging a link between rural labour and empire. ${ }^{41}$

In the last lines of Book Three of The Fleece, Dyer depicts the transportation of the woolen textiles to their destiny on the market in London. This section is described by Dyer (in the 'Argument') as 'Description of the Thames, and the port of London':

$$
\text { Ev'n now behold, }
$$

Adown a thousand floods the burden'd barks,

With white sails glistening, through the gloomy woods

Haste to their harbours. See the silver maze

Of stately Thamis, ever chequer'd o'er

With deeply-laden barges, gliding smooth

And constant as his stream: in growing pomp,

By Neptune still attended, slow he [the Thames] rolls

To great Augusta's mart, where lofty Trade,

Amid a thousand golden spires enthron'd,

Gives audience to the world: the strand around

Close swarms with busy crowds of many a realm.

What bales, what wealth, what industry, what fleets!

Lo, from the simple fleece how much proceeds.

As the wool is transported down the river to the market of London in 'burdened barks', Dyer imagines the Thames 'chequer'd over / with deeply-laden barges'. The classical allusion to Neptune helps elevate the scene, reminding us of the lofty ideals of virtue, peace and prosperity that the georgic associates with commerce. The wool, product both of agriculture and manufactures, arrives at the market in Augusta, the poetic name for London (used in Pope's Windsor Forest and James Thomson's The Seasons (1726-1746)). Dyer's London, with 'its thousand golden spires', consciously recalls the 'glitt'ring spires' of Pope's Windsor Forest (1. 377), but augments the piety of Pope's image by fleshing out the trope of the 'mart' (market) by depicting the 'busy crowds' of people (sailors, porters, merchants) around the bales of wool on the strand or quay: a trope of mercantile cornucopia. The final two sentences recapitulate the georgic connection between trade and national prosperity in the spectacle of the port. The scene of the busy quay recalls both Scott's painting and Boitard's satire.

\footnotetext{
${ }^{41}$ Karen O'Brien, 'Imperial georgic, 1660-1789', in The country and the city revisited: England and the politics of culture, 1550-1850, ed. Gerald MacLean, Donna Landry, and Joseph P. Ward (Cambridge: Cambridge University Press, 1999), 160-79; Markman Ellis, 'Georgic Poetry and the problem of unfree labour', in Discourses of Slavery and Abolition, ed. Brycchan Carey, Markman Ellis, and Sarah Salih (London: Palgrave, 2004).
} 
In the first lines of Book Four, the poem remains located within the port of London, now imagining the wool loaded into the great ocean going ships of the export trade ('Book IV: Our manufactures exported').

Now, with our woolly treasures amply stor'd,

Glide the tall fleets into the wid'ning main,

A floating forest: ev'ry sail, unfurl'd,

Swells to the wind, and gilds the azure sky.

Here Dyer embeds the forest of masts trope ('a floating forest') in the trope of mercantile cornucopia.

Meantime, in pleasing care, the pilot steers

Steady; with eye intent upon the steel,

Steady before the breeze the pilot steers:

While gaily o'er the waves the mounting prows

Dance, like a shoal of dolphins, and begin

To streak with various paths the hoary deep. ${ }^{42}$

As the stanza continues Dyer revises the mercantile cornucopia trope again, imagining the ships pouring out from the Thames, exporting woolen textiles over the globe. Scott's quayside and river paintings make use of a visual georgic, linking river labour to the scene of the market and to international trade, and thereafter the higher purposes of national prosperity and empire. Like the georgic, they find a place within the larger view for the labouring poor: in the verse, the shepherd and the weaver, in the painting the waterman and the porter. While both verse and painting celebrate the place of the labouring poor within the world of the polite and the prosperous, neither form takes much interest in the everyday facts of the labourers work, nor in their amelioration and emancipation.

\section{Bridge}

These central aspects of georgic - the promotion of labour's virtue and the suppression of its vulgar hardships - are reiterated in Scott's bridge paintings, particularly in the opposition he establishes between grand public projects and the quotidian ordinariness of riverine employment. Scott's views of the two London bridges were amongst his most successful, if measured by the number of commissions. The view of old London Bridge, for example, was executed eleven times from the same viewpoint, and engraved in a popular print by Pierre Canot. The immediate appeal of the old London Bridge paintings, such as A view of London Bridge before the alteration in 1757 (undated, Fishmongers' Company) [Figure 6], is the diverse jumble of medieval buildings on the bridge, viewed in a wide prospect from downriver at $\mathrm{St}$ Olave's Stairs. While the painting reflects a kind of nostalgia for medieval London, it was painted within the context of debate on the bridge's improvement: proposals for

42 John Dyer, The Fleece. A Poem. In four books (London: Printed for R. and J. Dodsley, in Pall-Mall, 1757). 
the removal of the habitations to improve the flow of traffic over the bridge were commonplace in the $1750 \mathrm{~s}$, and the project was finally undertaken in 1760 . The foreground of the view showed a scene of industry: to the left watermen's boats drawn up at Tooley stairs, where several men fish by line and net. The dangerously swift white water passing through the bridge's narrow arches is clearly depicted, as are various men at work maintaining the bridge piers and superstructure. While one lighter is passing under the bridge's central span, another is working up stream behind it: to the right a single larger ship is moored in the Pool. While a bridge suggests itself as a medium for transportation and a 'channel of movement' from bank to bank, this encumbered bridge is visually re-imagined as a cityscape, with little indication of the bridge traffic. ${ }^{43}$ Instead, the focus of activity is on the river surging through the closely set piers, the boatmen and fishers in the pool below, and the encircling ring of buildings.

By contrast, the scene at Westminster Bridge articulates a more complicated notion of labour. The new bridge at Westminster was built by the Swiss engineer Charles Labelye between 1739 and 1750, after a longer period of promotion, legislation and funding led by the Henry Herbert, sixth Earl of Pembroke (c. 1689-1750), who died just before it opened. The bridge was approved only after a considerable public debate as to its utility and consequences, not only for established interests in the City and Westminster, but also for the watermen who plied their trade on the river there. The new bridge, paid for by lottery and direct grant from parliament, was a significant exercise in public works in the period, and was celebrated on completion as an example of the new grandeur of the metropolis. As Pope noted at the end of An Epistle to Burlington (1731), such public works represented the highest level of civic service, as the statesman

Bid Harbours open, public Ways extend,

Bid Temples, worthier of the God, ascend;

Bid the broad Arch the dang'rous Flood contain,

The Mole projected break the roaring Main;

Back to his bounds their subject Sea command,

And roll obedient Rivers thro' the land;

These Honours, Peace to happy Britain brings,

These are Imperial Works, and worthy Kings.

When Pope glossed these lines, in a footnote added in 1735, he described how they addressed the 'public works which become a prince', and provided a specific example: 'The proposal of building a Bridge at Westminster', which 'had been petition'd

43 The term 'channel of movement' is derived from Jay Appleton, The Experience of Landscape (London: Wiley, 1975), p. 119. 
against and rejected: but in two years after the publication of this poem [in 1731], an Act for building a Bridge pass'd thro' both houses'. ${ }^{44}$

The planning and construction of Westminster Bridge was articulated through the 'discourse of improvement', a term often associated with the agrarian revolution in methods of husbandry, but also used to describe the rhetoric of economic 'progress' more generally, both to individuals and to society as a whole. ${ }^{45}$ An anonymous apologist argued in Gephyralogia (1751) that 'public utility' was the guiding principle of the Westminster Bridge project, despite opposition by local interests:

When compared with the great advantages, or at least conveniences, that may be expected to flow from a bridge at Westminster to a very great part of the kingdom, the interest of the watermens company, and the unreasonable prejudices of those citizens, who formed their judgment upon narrow and weak principles, were not to be brought into competition with them by the British parliament, whose care should extend equally to the whole community. ${ }^{46}$

Large-scale public works, especially complicated and expensive engineering projects like bridge-building, were understood to reflect a modernizing, rational, civic economy, as Alison O'Byrne has argued. ${ }^{47}$ Adam Smith (1776) was one of many who argued that large-scale investment in transport infrastructure (bridges, canals, roads) facilitated 'the Commerce of the Society', by opening new markets, encouraging the circulation of goods, and, by the increase in prosperity, improving the manners of the people. ${ }^{48}$ As the anonymous author of Gephyralogia suggested, the public benefits ('advantages' and 'conveniences') that would 'flow' from the projects successful completion outweighed not only its cost and labour, but also its local opposition. 'Flow' was a key notion: the bridge would increase the flow of goods and persons across it, and yet not impede the riverine flow of water, shipping, and goods through it.

\footnotetext{
44 Alexander Pope, 'Epistle to Burlington', in Epistles to Several Persons (Moral Essays), ed. by F. W. Bateson, in The Poems of Alexander Pope, III, part 2 (1961), p. 156, 1l. 197-204.

45 On 'improvement' in general, see: Stephen Daniels, 'Humphry Repton and the Improvement of the Estate', in Fields of Vision: Landscape Imagery and National Identity in England and the United States (Cambridge: Polity, 1993), pp. 80-111; Andrew McRae, God Speed the Plough: The Representation of Agrarian England, 1500-1660 (Cambridge: Cambridge University Press, 1996), pp. 156-66.

46 Gephyralogia. An Historical Account of bridges, Antient and Modern, From the most early Mention of them by Authors, down to the present Time (London: C. Corbett, 1751), p. 71.

47 Alison O’Byrne, 'Composing Westminster Bridge: Public Improvement and National Identity in Eighteenth-Century London', in The age of projects, ed. by Maximillian E. Novak (Toronto: University of Toronto Press, 2008), pp. 243-270.

48 Adam Smith, An Inquiry into the Nature and Causes of the Wealth of Nations, ed. R.H. Campbell and A.S. Skinner, 2 vols, (Oxford: Clarendon Press, 1976), I, 163.
} 
In a painting such as The Building of Westminster Bridge (1742, Yale Centre for British Art) [Figure 7], the process of construction itself was made the spectacle. The mighty civic labours of the bridge builders are contrasted with the quotidian busy-ness of the watermen in the foreground: a lighter and a barge being rowed upstream by lightermen, a single-masted boatman's hoy holding a party of gentlefolk, and in the background, further parties of leisure. The incomplete bridge is shown with the wooden scaffolding and partially completed stonework for four of the projected fifteen arches, dating the scene to 1742 . The works are accurately delineated, for, as well as stockpiles of stone on the Westminster riverbank where the bridge footings were located, the innovative horse-driven pile-driver designed by James Vauloué can be seen on the left, next to the equally innovative prefabricated sinking caisson that Labelye used to build the piers. In contrast to the civic imagination of these grand labours of engineering, numbers of masons can be seen at work amongst the scaffolding and stone of the incomplete arches. ${ }^{49}$ In a georgic mode, Scott's painting establishes equivalences between the public labour of the bridge projectors (engineers, noblemen, lawmakers), and the ordinary labours of builders, masons, and the everyday riverine work of watermen and boatmen that passes beneath it. But, also like the georgic, the painting establishes equivalences between these varieties of labour, high and low, and contrasts them with the polite and seemingly leisured world of the boatmen's passengers.

Early observers were struck by the classical proportions of the bridge's construction, and linked it to civic virtue. 'This Bridge', observed one commentator when it first opened to the public in December 1750, 'is allowed to be one of the finest in the world. It is built in a neat and elegant taste, and with such simplicity and grandeur, that whether viewed from the water, or by the passenger who walks over it, it fills the mind with an agreeable surprise'. ${ }^{50}$ In occasional verses entitled 'On Westminster Bridge', first published in the London Magazine, the poet imagines the Thames being visited by the river gods of great European rivers with capital cities on them (Rhine, Danube, Tigris, Seine), attracted to London by its fame and prosperity.

Allur'd by fame who told what fleets he bore,

What wealth, what splendor dignify'd his shore,

As from the sea, high surging on his tide,

Thro' woods of ships they with amazement ride,

The poet here adopts the forest of masts trope ('woods of ships') to signal of the river's prosperity. Travelling up-river, the visiting gods first encounter London Bridge, but confused by the buildings, almost fail to recognize it as a bridge at all. After passing

\footnotetext{
49 R.J.B. Walker, Old Westminster Bridge: The Bridge of Fools (Newton Abbott: David and Charles, 1979).

50 'A Description of the New Bridge at Westminster', Universal Magazine of Knowledge and Pleasure, 7:49 (December 1750), p. 275.
} 
underneath its 'press'd arches', they continue up-river, encountering the City's 'mingling spires, and Paul's stupendous dome' (after Pope), until they discover 'the last wonder', the new Westminster Bridge, which leaves them 'Astonish'd! Ravish'd!' The river gods then address their praises to the new bridge's light appearance and innovative engineering, pressing Phoebus (Apollo), the Greek god associated with the foundation of Ilion (Troy), to offer his assistance to 'plan this bridge, and lend the workmen aid'. The poem's classicizing praise reaffirm the bridge as a noble work of public labour that reinforces the aristocratic grandeur of the city. ${ }^{51}$

The neoclassical symmetry of the new bridge was celebrated by Scott in his five paintings of the view through an arch of the bridge to the City beyond, such as Arches of Westminster Bridge (undated, c.1751, Yale Centre for British Art) [Figure 8]. This view had been undertaken already by Canaletto in 1746-47 (London Seen Through an Arch of Westminster Bridge), ${ }^{52}$ and later again by Philip James de Loutherbourg, and in the nineteenth century by Jacques-Laurent Agasse and J.M.W. Turner. ${ }^{53}$ Scott's arch views document the bridge's elegant stone engineering, but studiously ignore the surface roadway and thus the bridge's principal task of providing a path of locomotion between the two sides of the river. Instead, Scott examines the relationship of the bridge to the river flowing beneath it, and the traffic and labour of the river space. In this sense, the bridge is an interruption to the flow of the river. Scott allows a closer focus on quotidian river life: the boatman in his wherry proceeding downriver, the two men swimming, and above, on an unfinished part of the parapet, two workmen on wooden scaffolding. The bridge was surmounted by an oversize balustrade, and was interrupted at each pier by a domed niche designed to allow shelter to pedestrians. The workmen on their scaffolding are caught here pausing from their masonry to enjoy a tankard of ale that one passes to the other. The painting's lowlevel water view orients the viewer with the boatmen and the swimmers, and proposes a 'channel of movement' in the languorous flow of the river, taking the viewer's eye through the arch to the more complex built environment of the city beyond (Montagu House, the York Buildings Company's water tower, St Clement Dane's church tower). The lower viewpoint of the arch paintings, closer to the river itself, suggests identification with its labouring world, even in moments of leisure, and disperses the contrast between an aristocratic and civic cityscape established in paintings of the bridge under construction. In this way, Scott proposes that work in all its forms can be considered harmonious with what Pope calls 'Imperial Works'.

51 'On Westminster Bridge', London Magazine, or, Gentleman's monthly intelligencer, 19 (December 1750), p. 600; reprinted in Gephyralogia, pp. 132-33.

52 Canaletto, London Seen Through an Arch of Westminster Bridge (1747), Duke of Northumberland, oil on canvas $(59.69 \mathrm{~cm} \times 96.52 \mathrm{~cm})$

53 John Sweetman, The artist and the bridge: 1700-1920 (Aldershot: Ashgate, 1999), p. 35 


\section{Conclusion}

Scott's river views have often been read as offering the viewer an image of a stable, unified, polite and ordered city. This essay has argued that this view of Scott's paintings, while arguably appropriate to a follower of Canaletto, limits our understanding of the works. His paintings offer a more complicated account of the river and the city, impelled not only by his established business in maritime painting, but also by mid-century discourse on trade and commerce, and the virtue of labour. As the georgic poetry of the period explores, commerce and labour were key locations for debate about the place of virtue in civil society. These debates focus Scott's discussion, in his paintings, of the virtue of river employments, and their relationship to the larger national themes invoked by the spectacle of the river: of commerce in the pool and on the quay, and of improvement and public works. Scott's low view-point and compositional frame allows in his river views a distinctive concentration on the ordinary world of the river labourer: boatmen, sailors, porters, custom's agents, as well as their passengers and customers. His paintings construct the river as a complex social space in which different forms of labour and trade are brought into proximity and interaction with the polite elite and the themes of commerce, nation and empire. 
Illustrations

Figure 1: Samuel Scott, The Thames and the Tower of London Supposedly on the King's Birthday, 1771, oil on canvas, 101 x 193 cm, Yale Centre for British Art, Paul Mellon Collection.

Figure 2: Thomas Luny, The Port of London, 1798, oil on canvas, 55.2 x $86 \mathrm{~cm}$, Yale Centre for British Art, Paul Mellon Collection.

Figure 3: School of Samuel Scott, The Entrance to the River Fleet, undated, 112 x $59 \mathrm{~cm}$, Guildhall Art Gallery, City of London.

Figure 4: Samuel Scott, Custom House and Wool Quay in the year 1757, 1757, oil on canvas, 137.2 x $104.1 \mathrm{~cm}$, The Worshipful Company of Fishmongers, London.

Figure 5: Louis Philippe Boitard, The Imports of Great Britain from France. Humbly addressed to the Laudable Associations of Anti-Gallicans, and the generous promoters of the British Arts $\mathcal{E}^{2}$ Manufactories (London: Invented \& Engrav'd by L.P. Boitard. Publish'd according to the Act of Parliament, March 7th 1757 by John Bowles and Son at the Black Horse in Cornhill, 1757), etching, 24.8 x 34.8 cm, Guildhall Art Gallery, City of London.

Figure 6: Samuel Scott, A view of London Bridge before the alteration in 1757, undated c. 1757, oil on canvas, $67.3 \times 114.3 \mathrm{~cm}$, The Worshipful Company of Fishmongers, London.

Figure 7: Samuel Scott, The Building of Westminster Bridge, 1742, oil on canvas, $68.6 \mathrm{x}$ 119.4 cm, Yale Centre for British Art, Paul Mellon Collection.

Figure 8: Samuel Scott, Arches of Westminster Bridge, undated, c.1751, oil on canvas, 104.8 x $118.1 \mathrm{~cm}$, Yale Centre for British Art, Paul Mellon Collection. 